\title{
Do medical students have a positive outlook on the world?
}

\begin{abstract}
Introduction. Upon entering diverse fields of medical science, young people are on the cusp of adulthood. They change their environment and take on new responsibilities, which often translates to stress and depression.

Aim. The main objective of the work was to assess the psychological health in students of Medical University of Lublin.

Material and Methods. The research tool was a questionnaire containing information regarding mental health of first-year students of medicine. The results were statistically analysed in Statistica 11.0, utilising Pearson's Chi Squared test of independence, with significance set at $\mathrm{p}<0.05$.

Results. Most respondents (55.79\%), whether male or female, rarely feel sadness. About $43 \%$ of respondents replied that they employ different strategies of coping with stress. $33.47 \%$ of all students stated that whenever any problems appear they look for support from their families. Generally, around $47 \%$ of all students are happy with their lives. There were, statistical signification between the sex of the students and psychological well-being, and between the sex and the ways of dealing with depression.

Conclusions. Despite the significant stress to which these young people are exposed, they are relatively strong mentally and have a positive outlook towards the lives.
\end{abstract}

Keywords: young people, stress, psychological health.

DOI: $10.1515 /$ pjph-2016-0026

\section{INTRODUCTION}

Well-being is a multi-faceted concept that is dependent upon psychological, physical or spiritual health. It has influence over both social relationships and the ability to cope with stress [1,2]. Indeed, personality shapes the level of satisfaction with life [3] and knowledge about healthy lifestyle in the spiritual, psychological, and physical spheres is proffered within the course of studying the medical sciences [4]. Therefore, students of the Faculty of Medicine and Dentistry become an example to follow in the context of care for personal well-being [4]. Overall, they have generally positive attitudes towards life. Yet, in comparison with students of other faculties who are of the same age, students of medical sciences are more likely to be impacted by teaching practices [5], and more likely to experience stressful situations [6]. This is because medical practice requires, after all, emotional involvement in aspects of human suffering or death [7].

According to Hippocrates, the "Father of Medicine", a prospective doctor should have natural skills, a strong personality, perseverance and the ability to devote themselves to work [8]. Still, the desire to help people, the desire for social prestige and even the desire to please parents have impact upon medical training. Yet, intrinsic motivation produces much better results than extrinsic motivation and has a more positive effect on creativity [9]. Starting a career in the medical sphere, emotional intelligence (defined as the ability to perceive, to express, to understand and control the emotions) is important, as this translates into the evolution of empathy, the development of a positive doctor-patient relationship, team skills and stress management [10].

Therefore, there is a strong relationship between personality, level of motivation and emotional intelligence in dealing with stress that arises in the course of such studies and in the practicing of the medical sciences. High stress levels might be a risk factor for headaches, gastrointestinal disorders, the development of coronary artery disease, depression or addiction to drugs or alcohol [11], while, undoubtedly, care and attention to well-being help reduce stress levels [6].

\section{AIM}

The main objective of the work was to assess mental health, well-being and satisfaction with life and ways of coping with stress among first year students of the Medical University of Lublin. Moreover, an attempt was made to ascertain whether a statistical correlation exists between the studied traits and the gender of the respondents.

\section{MATERIAL AND METHODS}

During the study, the authors looked at 242 students (148 women and 94 men). They were all first-year students of medicine, aged 18-30 (median 20 years) (Figure 1). 


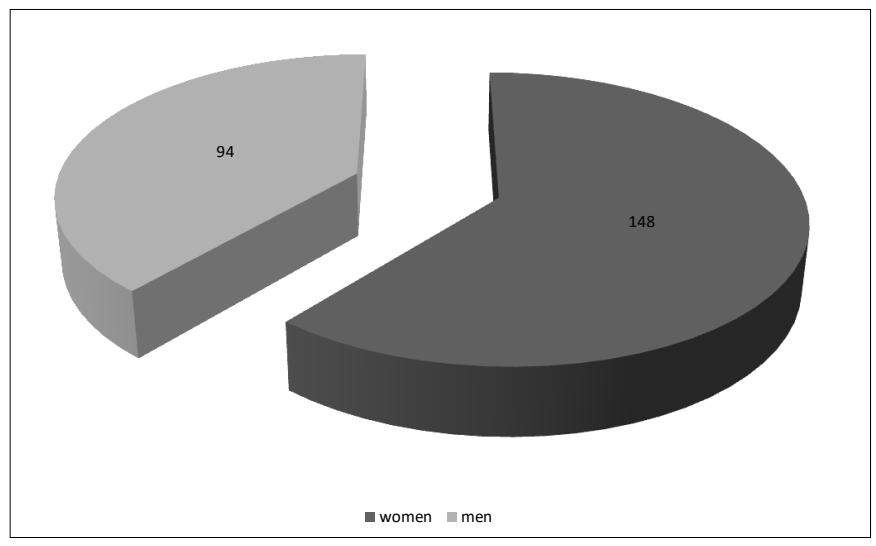

FIGURE 1. Participants according to gender.

The study was conducted in March 2016 (the 2015/16 academic year). The research tool was an anonymous questionnaire which took into account, among others, age, sex and place of residence as well as other information regarding their mental health, approaches to dealing with bad mood and depression, as well as the life satisfaction degree. The results were statistically analysed using Pearson's $\mathrm{Chi}^{2}$ test of independence, with significance set at $\mathrm{p}<0.05$, using the program Statistica 11.0. Following this, the results were summarized in the form of figures.

\section{RESULTS}

In the research, students provided answers to questions about: psychological well-being, ways of dealing with a bad mood, overall satisfaction with life, and where they sought help with depression symptoms.

The response to this question demonstrated statistical significance between psychological well-being and the sex of the students (Chi ${ }^{2}$ Pearsona: 12.9481, $\mathrm{df}=4, \mathrm{p}=0.011532$ ).

Regarding the question of how often they felt sad or depressed, most respondents $(55.79 \%)$, whether male or female, declared that they rarely were. Broken down by gender, $68 \%$ of all male respondents stated so, while $48 \%$ of all females did the same. Among those who provided positive replies, almost $26 \%$ of all males and $40 \%$ of all females chose to state 'often'. The least number of respondents $(0.68 \%$ of all those questioned and limited to females alone) put forward that they always felt sad or depressed. On the other hand, $2.13 \%$ of all males and $0.68 \%$ of all females responded that they never suffered from feelings of depression and sadness (Figure 2).

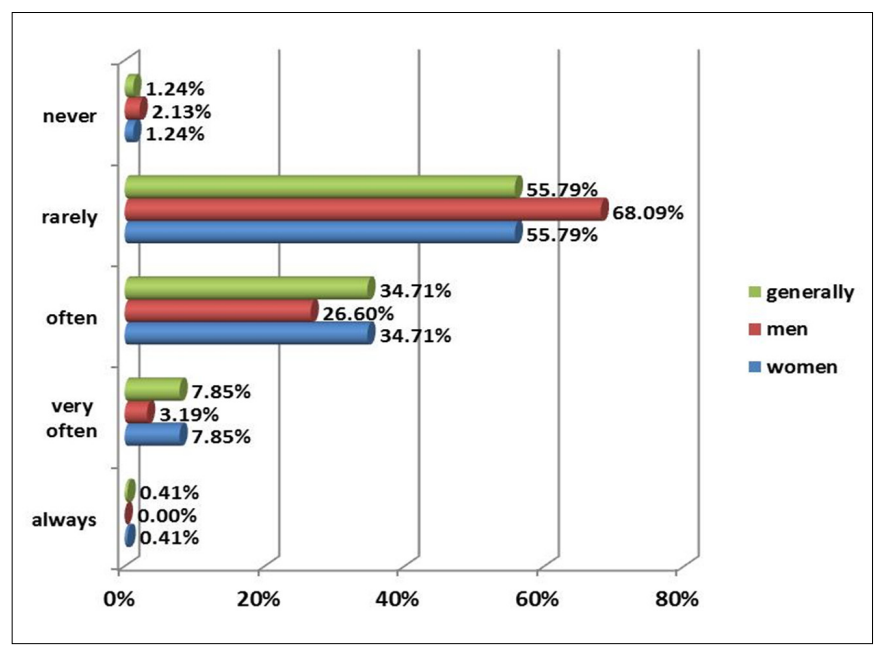

Upon the analysis of the responses, no statistical dependence was found between the ways of coping with stress and the sex of the students (Chi ${ }^{2}$ Pearsona: $12.5341, \mathrm{df}=11, \mathrm{p}=0.324860$ ).

The research also focused on how the participants managed situations loaded with stress. Most respondents put forward that they used a variety of ways (nearly $43 \%$ of the entire test population; $43.61 \%$ of all males and $42.57 \%$ of all females). A large group of students $(20.66 \%$ of all respondents; $16 \%$ of all males and $+23 \%$ of all females) declared that they looked for support from their friends (Figure 3).

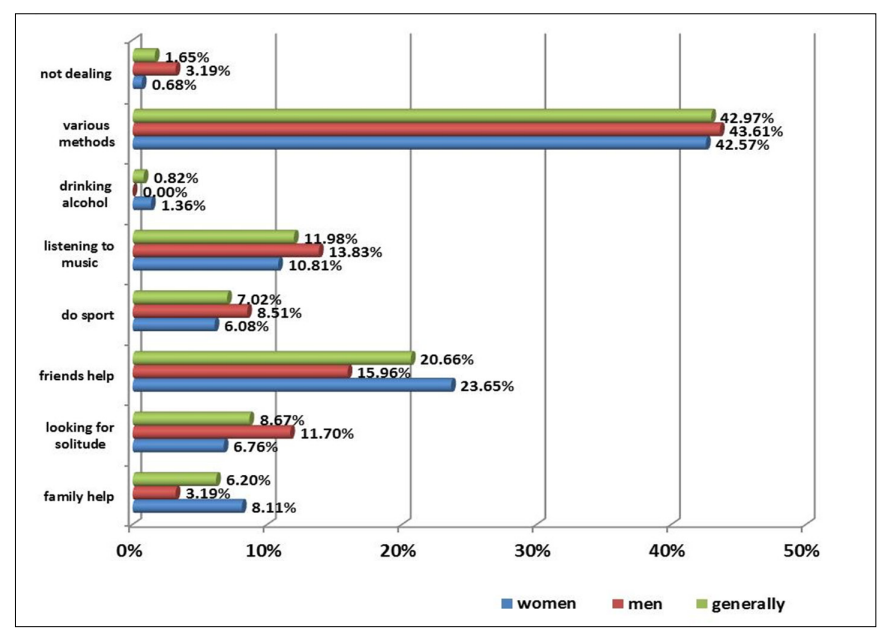

FIGURE 3. How do you deal with bad moods?

Some statistical significance was revealed between the ways of dealing with depression and the sex of the students (Chi ${ }^{2}$ Pearsona: 20.4827, $\mathrm{df}=6, \mathrm{p}=0.002271$ ).

Regarding the question of what would be done regarding self-recognition of depression, most of the surveyed (33.47\%; $39 \%$ of all females) stated that they looked for support from their families, while $26.35 \%$ of all female participants sought advice from friends. However, $25.53 \%$ of all the men surveyed stated that they had no idea what to do, while $24.47 \%$ sought support among family. Still, $21.28 \%$ of all participants did not seek any outside help at all. In contrast, $6.38 \%$ of all men surveyed and $6.08 \%$ of all female participants used multiple ways of coping with depression, yet only $7.85 \%$ of all respondents sought the help of psychologists (Figure 4).

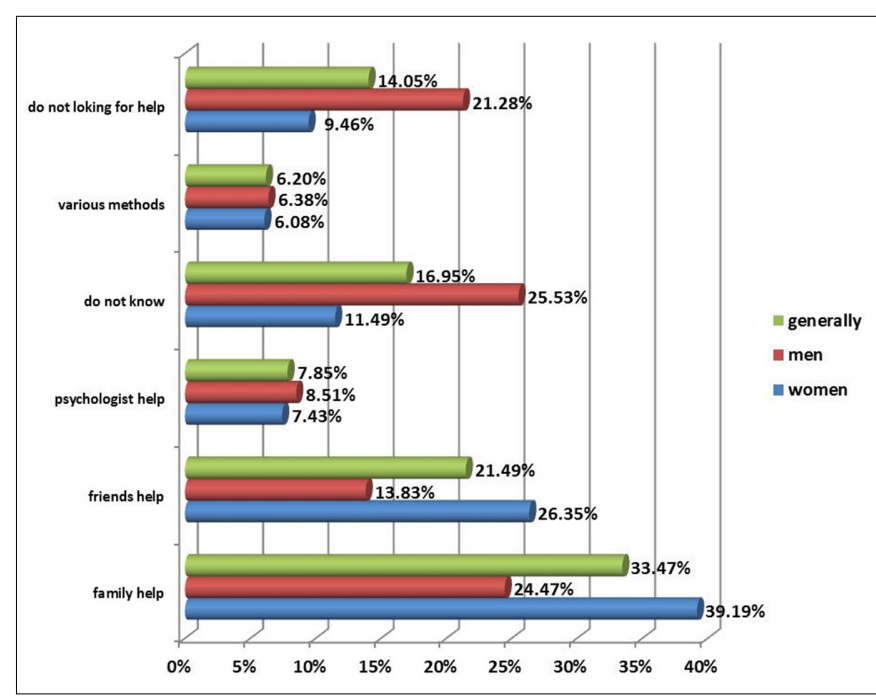

FIGURE 4. What would you do if you notice symptoms of depression?

FIGURE 2. How often do you feel sadness or depression? 
No statistical dependence was found between life satisfaction and the sex of the students $\left(\mathrm{Chi}^{2}\right.$ Pearsona: 8.90996, $\mathrm{df}=4$, $\mathrm{p}=0.063390$ ).

Regarding the question of whether the surveyed are happy with their lives, most respondents (47.11\%: $40 \%$ of all males, $52.03 \%$ of all females) replied 'rather yes', while $52 \%$ of all male participants and $36 \%$ of all females stated 'yes'. The least percentage of respondents $(2.48 \%)$ replied negatively $(1.06 \%$ of all males surveyed and $3.38 \%$ of females surveyed). However, $+/-1 \%$ of all male participants and $4 \%$ of all female participants had no opinion on happiness (Figure 5).

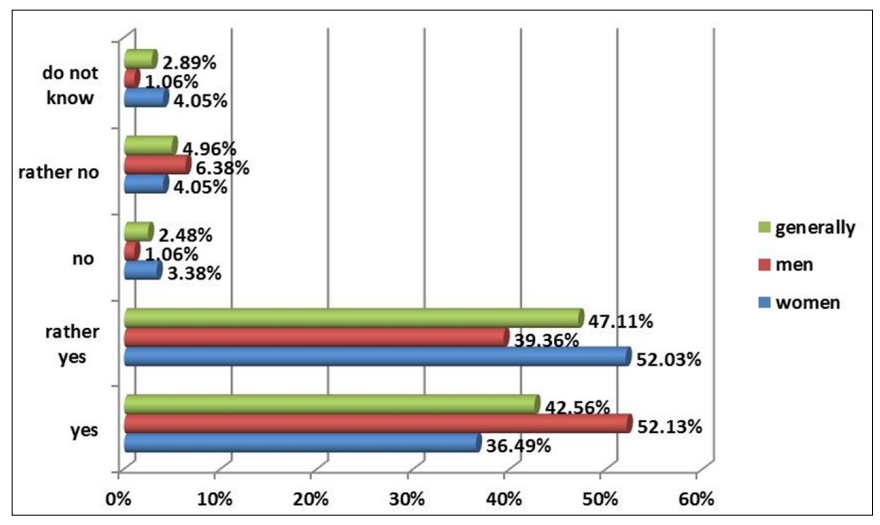

FIGURE 5. Are you happy with your life?

\section{DISCUSSION}

In today's world, people should be mentally tough. Indeed, in order to survive, it is extremely important to be able to cope with stressful situations. Medical students are assumed to have outstanding personality traits, among these being emotional balance and stable mental health, which would enable them to endure the pitfalls of their future profession.. Still, stress tends to appear. Our study was conducted among first-year students. They have just started a new stage of life, and often, apart from a new social environment, they change their place of residence. Moreover, they take on more responsibilities, and are immersed in the difficult study of life sciences.

In our research, most respondents $(55.79 \%)$, whether male or female, declared that they rarely felt sad and depressed. Almost $26 \%$ of all males and $40 \%$ of all females chose to state 'often'. The least number of respondents $(0.68 \%$ of all those questioned and limited to females alone) put forward that they always felt sad or depressed. In the work of Szczepańska et al. [12], based upon a study of students of physiotherapy in Wroclaw, $15 \%$ of all first year students opined that they felt the symptoms of bad mood (feelings of poor health). However, in the time limited (2 weeks prior to the survey) study undertaken by Białkowska et al. [13] regarding feelings of despondency, sadness and hopelessness, about 11.6 of all male participants and $19.1 \%$ of all female participants considered that they had felt so.

In our study, most respondents said that they used various ways to cope with stress (nearly $43 \%$ of the entire number of participants; $43.61 \%$ of all males and $42.57 \%$ of all females). A large group of students $(20.66 \%$ of all respondents; $16 \%$ of all males and $+23 \%$ of all females) declared that they looked for support among their friends. These results differed slightly from those revealed in the work by Marek et al. [14], in which almost $50 \%$ of the students of the Medical Academy in Gdańsk sought the support of their friends. Still, both this very study and the one by Marek et al. reavealed a similar proportion of participants ( $12 \%$ of all surveyed verses $9 \%$ of all questioned) who coped with stress through listening to music. It is comforting to know that least respondents sought relaxation drinking alcohol (in our study: $1.36 \%$ and female alone; in that of Marek et al.: almost 4\% of all respondents) [14]. Regarding those who felt that they had no means of dealing with stress, in our study, $1.65 \%$ of all surveyed felt so, while the work of Marek et al. revealed a similar figure - namely $1.9 \%$ of all participants [14]. The survey undertaken by Skrzypek et al. [15] showed that a significant number of female participants, unlike their male counterparts, sought professional support in order to cope with stress $(\mathrm{p}=0.0001)$. Moreover, women were more likely to resort to passivity and leaving university $(\mathrm{p}=0.01)$, and also to resort to self-injury and negativity $(\mathrm{p}=0.01)$, as well as networking with friends $(p=0.01)$ [15]. In our research, no statistical dependence was found between the choice of stress release and the sex of the student participants.

Among medical students, most of the surveyed (33.47\%; $39 \%$ of all females) when they realized they suffer from depression depression stated that they looked for family support, while $26.35 \%$ of all female participants sought advice from friends. However, $25.53 \%$ of all the males surveyed stated that they did not know what to do, while $24.47 \%$ sought support among family. Only $7.85 \%$ of all respondents sought the help of psychologists. In contrast, Szczepańska et al. [12] noted that up to $49 \%$ of all first year students declared that, in the event of personal problems, they would seek professional psychological help.

Most medical students (47.11\%: $40 \%$ of all males, $52.03 \%$ of all females) are "rather" happy with their lives. The least percentage of respondents $(2.48 \%)$ replied negatively $(1.06 \%$ of all males surveyed and $3.38 \%$ of females surveyed). In contrast, a CBOS research [16] puts shows that $71 \%$ of those whom they surveyed are quite satisfied with their lives, while $20 \%$ are satisfied. Regarding the Polish population alone, $25 \%$ of those who participated in the survey reported an average degree of satisfaction, while $3 \%$ stated that they are disillusioned with the progress that is happening in their lives. These results are similar to those revealed by the Main Statistical Office in Warsaw [17] in the first half of 2015. Herein, 78\% of the population of Poland of the age of $+/-16$ years reported that they are generally satisfied with their lives, and 9\% report that they are very happy. As in the our study and that by CBOS [16], some $4 \%$ of the test population reported that they are dissatisfied with the lives they lead, and $1 \%$ are very dissatisfied. The work undertaken by the Main Statistical Office in Warsaw [17] can also be mentioned here. It has shown that young people often believe that they are more satisfied with life than are older people. Indeed, in the youngest age category (16-24 years), some $85 \%$ of respondents declared an overall positive satisfaction with life [17].

\section{CONCLUSION}

On the basis of the test results, it might be concluded that first year students of medical faculties are quite satisfied with their lifestyles and they rarely feel sadness or the effects of depression (which crosses genders). To overcome such times of emotional lows, however, students have different approaches. Some look for support from friends, yet the majority reach out to their families. This very study revealed some statistical 
significance of sex of the students and psychological wellbeing and between the sexes and the ways used to deal with depression.

Finally, it can be stated that, despite the stress to which young people are exposed when entering adulthood, they are relatively strong mentally and hold a positive outlook on the world. In addition, young people trust their friends and family and reach out to them when affected with bouts of depression.

\section{REFERENCES}

1. McDowell I. Measures of self-perceived well-being. J Psychosom Res. 2010;69:69-79. doi:10.1016/j.jpsychores.2009.07.002.

2. Park H, Suh BS, Kim WS, et al. Character profiles and life satisfaction. Compr Psychiatry. 2015;58:172-7. doi: 10.1016/j.comppsych.2014.12.013.

3. Lyubomirsky S, Sheldon KM, Schkade D. Pursuing Happiness: The Architecture of Sustainable Change. Rev Gen Psych. 2005;9,(2):111-31. doi: 10.1037/1089-2680.9.2.111.

4. Nacar M, Baykan Z, Cetinkaya F, et al. Health promoting lifestyle behaviour in medical students: a multicentre study from Turkey. Asian Pac J Cancer Prev. 2014;15(20):8969-74. doi:10.7314/APJCP.2014.15.20.8969.

5. Rogers ME, Creed PA, Searle J. Person and environmental factors associated with well-being in medical students. PAID. 2012:52:472-7. doi:10.1016/j.paid.2011.11.006.

6. Slonim J, Kienhuis M, Di Benedetto M, Reece J. The relationships among self-care, dispositional mindfulness, and psychological distress in medical students. Med Educ Online. 2015;20:27924. doi: 10.3402/meo.v20.27924.

7. Srivastava K, Raju MSVK, Saldanha D, et al. Psychological well-being of medical students. MJAFI. 2007;63:137-40.

8. Millan LR, Azevedo RS, Rossi E, et al. What is behind a student's choice for becoming a doctor? Clinics. 2005;60,(2):143-50.
9. Kusurkar RA, Croiset G, Galindo-Garré F, Cate OT. Motivational profiles of medical students: Association with study effort, academic performance and exhaustion. BMC Med Edu. 2013;13(87). doi: 10.1186/1472-692013-87.

10. Yusoff MSB, Esa AR, Pa MNM, et al. A Longitudinal study of relationships between previous academic achievement, emotional intelligence and personality traits with psychological health of medical students during stressful periods. Education for Health. 2013;26(1). doi: 10.4103/13576283.112800 .

11. O’Rourke M, Hammond S, O'Flynn S, Boylan G. The medical student stress profile: a tool for stress audit in medical training. Med Edu. 2010;44:1027-37. doi:10.1111/j.1365-2923.2010.03734.x.

12. Szczepańska J, Klin Z, Jaroszewska A, Ciesielski R. Zaburzenia nastroju w populacji studentów Wydziału Fizjoterapii AWF we Wrocławiu. Część 1. Fizjoterapia. 2008;16(3):69-78.

13. Białkowska J, Mroczkowska D, Zomkowska E, Rakowska A. Ocena zdrowia psychicznego studentów na podstawie Skróconego Kwestionariusza Zdrowia Pacjenta. Hygeia Public Health. 2014;49(2):365-9.

14. Marek K, Białoń P, Wichowicz H, et al. Przesiewowa ocena rozpowszechnienia objawów depresyjnych i lękowych wśród studentów Akademii Medycznej w Gdańsku. Psychiatr. 2005;2(4):217-24.

15. Skrzypek M, Piątkowski W, Brysiewicz A, Wszędyrówny M. Analiza jakości życia studentów w kontekście stylu radzenia sobie ze stresem. Raport z badań. Annales UMCS. SECTIO I. 2001;24(21):261-75.

16. Centrum Badania Opinii Społecznej (CBOS), Komunikat $z$ badań, Zadowolenie z życia, Warszawa; 2013. Availabe: www.cbos.pl/SPISKOM. POL/2013/K 001 13.PDF.

17. Główny Urząd Statystyczny, Subiektywny dobrobyt w Polsce w 2015 roku. 2015. Available: http://stat.gov.pl/download/gfx/portalinformacyjny/pl/defaultaktualnosci/5486/20/1/1/subiektywny_dobrobyt_w_ polsce_w_2015r.pdf.

\section{Corresponding author}

Marta Lis-Sochocka

Chair and Department of Histology and Embryology

with Experimental Cytology Unit, Medical University of Lublin

11 Radziwiłłowska Str., 20-080 Lublin, Poland

tel. 814486153

E-mail: martasochocka@wp.pl 